\title{
Early Use of Corrective Lenses in Spanish Colonies of the Americas Including Parts of the Future United States: Reference to Viceroy Luis de Velasco (the Son)
}

\author{
MARIA CALVO, BS, MS, PhD and JAY M. ENOCH, BS, OD, PhD, DrsSci(hc), FAAO, FAAS \\ Departamento de Optica, Facultad de Físicas, Universidad Complutense, Madrid, Spain (MC), School of Optometry, University of \\ California, Berkeley, California (JME)
}

\begin{abstract}
We discuss many aspects of a reproduction of a formal painting from the XVIth century. It is a portrait of Viceroy of New Spain Luis de Velasco, El Joven or Hijo (son-see text), found at the Museum of the Pecos National Monument (near Pecos and Santa Fe, New Mexico). A formal portrait of each Viceroy of New Spain was created, and this one was painted during de Velasco's first term as Viceroy (1590 to $1595 \mathrm{AD})$. In this depiction, he is seen wearing spectacles. To our knowledge, this is the first known reference suggesting the introduction of this form of visual correction in the Spanish Colonies in the Americas and in the future United States. There are three known portraits of Luis de Velasco (son): One painting, which included his father and significant others, hangs in the Colegiata (a small cathedral) de San Luis near Valladolid, Spain. In this portrayal, he was shown as a young man without a spectacle correction. And there are two viceregal portraits (Term 1, 1590 to 1595; Term 2, 1607 to 1611) in which he wears the same spectacle correction (these are located in Mexico City). (Optom Vis Sci 2003;80:681-689)
\end{abstract}

Key Words: spectacle corrections, The Americas, Viceroy Luis de Velasco (father and son), early optical devices in the Spanish colonies of the Americas

1 $\mathrm{n}$ this article, we address the first known portrait of an individual depicted as wearing a spectacle correction who was recorded as residing for most of his life in New Spain including territories of the future United States. That individual was Luis de Velasco (El Joven = young man, or Hijo = son), an early Viceroy representing Spain in the Americas.

Don Luis de Mendoza served as first Viceroy (1535 to 1549 AD). Luis de Velasco (father) served as the second Viceroy (1550 to 1564). His son was appointed for two terms as Viceroy, the eighth from 1590 to 1595 and the eleventh from 1607 to 1611 . Formal portraits (a mark of special distinction) were made of all Viceroys of the (they had multiple titles) New World, New Spain, and New Mexico. We believe we have now located the original portraits (see below). De Velasco (son) is depicted wearing the same spectacle correction in both of his viceregal portraits. There is evidence that "the son" traveled in the southwestern portion of the future United States of America including California, New Mexico, as well as in Florida during his terms of office, and he served his first term as Viceroy before settlement of Atlantic seaboard colo- nies developed by other European nations. There is a possible exception to this statement, the very brief Roanoke Island Settlement (the so-called "lost colony") in Pamlico Sound, North Carolina (1585 to ca 1590$)$.

\section{BACKGROUND}

Studies devoted to the history of lenses or optical devices for vision correction are included under the general topic of Archaeological Optics. ${ }^{1,2}$ One of the authors (JME) has sought to define lens use in ancient cultures and times. ${ }^{1-5}$ Briefly, the first known lenses date from ca 2625 to 2400 BC (4625 to 4400 years before the present time) (e.g., see Enoch $\left.{ }^{4}\right)$. These extraordinary optical elements were fabricated during Dynasties IV and V of the Old Kingdom of Egypt. ${ }^{1,2,4}$ These were not visual corrections, but rather complex, high-quality special lenses in "schematic-like" eyes of funerary statues. They included a truly remarkable form of eyefollowing illusion. The first visual corrections and magnifiers are not known. Lenses were also employed for burning glasses, time- 
keeping devices, etc., and lens-like objects were used as symbols of purity in religious settings, for medicinal use, as amulets and charms, as decorative elements (e.g., in jewelry and architecturally), etc.

Forms of concave mirrors were among the earliest visual corrections. ${ }^{5}$ These were already well known and employed in Roman times and were discussed by the Roman citizen Seneca (4 BC to 65 $\mathrm{AD})$. In his text "Natural Questions," he discusses not only concave mirrors already being used as visual corrections or magnifiers, but he also reports that he filled a round glass Roman flask with liquid and used it as a reading aid. ${ }^{1,5}$ In effect, he had created a lens serving as a refractive correction. ${ }^{1,5} \mathrm{He}$ also compared the optical qualities of this lens to those of existing mirrors used for comparable purposes. Was this the first use of a flask filled with fluid to be used as a lens? This seems unlikely.

Spectacle lenses first appeared in ca $1280 \mathrm{AD}$, most probably in Nothern Italy ${ }^{6-8}$ Between the early Egyptian utilization of lenses, the time of Seneca, and the first announcement of spectacles in Florence, a number of lenses or lens-like objects have been described in quite a variety of locations (Western, the Levant, the Americas [e.g., Moche peoples of Peru], etc.). ${ }^{1-5}$ The time period between the first-known Egyptian lenses and the first description of spectacles in Florence spanned more than three millennia. During that period, such items would have had great value and probably were developed and used by artisans (and later monks) for detailed and visually demanding tasks and seem to have been employed on a sporadic basis.

Spectacle corrections, per se, after their first description, came into relatively broad use after only a few decades. ${ }^{7,9}$ This suggests that added developments had occurred in materials employed, manufacturing, cost control, development of some form of specification of lens power, and enhanced marketing techniques. Such issues are considered by Ilardi. ${ }^{7}$

The first known depictions of spectacle lenses recorded in Spain are dated about $1468 .{ }^{10}$ For early examples of visual corrections and spectacles in Spain, please refer to the extensive work of Devesa. ${ }^{6}$ Much ancient knowledge of optics must have been introduced into Spain and the European continent via the lengthy Arabic/Moorish influx into Iberia. We concentrate here on limited Western European developments because our interest is in the fate of a distinguished (most probably) Spanish-born gentleman who spent most of his life in "New Spain."

Early spectacles displayed in paintings and in sculptured items were not necessarily associated with the individual shown wearing these visual corrections, but rather they also could be a sign of special achievement or distinction in their lives (e.g., see Gibbs ${ }^{9}$ ). The first record of a pair of spectacles is found in a fresco in the Dominican Chapter House of St. Nicolo in Treviso, Italy (Veneto region). This appeared in the years just after Black Death, ca 1349 to $1350 .^{5,9}$ Two forms of mirror, a magnifier and a pair of spectacles are seen in this group of frescos. None of the holy fathers depicted are known to have utilized these optical devices. There are earlier depictions or descriptions of magnifiers and mirrors in the literature of a number of countries in the World. An often-quoted example, the Greek writer Aristophanes in "The Clouds," speaks of use of a burning glass/lens and, separately, a mirror in a box as well as a number of related phenomena.

There is considerable lack of knowledge regarding the use and early introduction of visual corrections in the Iberian peninsula. A number of meaningful factors contribute to this deficit. Historians do not commonly consider the history of Spain from these points of view, i.e., possible technological developments occurring during the Renaissance in Iberia are poorly recorded. ${ }^{10}$ A lack of bibliographic sources exists, and there is a difficulty in obtaining the relevant research material. ${ }^{6}$ The history of the Iberian peninsula during this time period is very complex and even "tormented" due to military invasions and numerous sociopolitical and religious problems. These factors apparently resulted in loss of relevant supporting evidence and limited availability of resources for study of the history of lens use for vision correction and other purposes.

A very important part of the history of Spain from the late $\mathrm{XV}$ th Century onward is associated with Columbus' voyages to the Americas from 1492. The subsequent development and expansion of resultant Spanish Colonies is of interest to us here. With expansion of the emerging Spanish Colonies, one assumes that a meaningful effort was needed from a technological and scientific point of view to address problems related to growing needs and demands in these colonies. Once again, there is a paucity of available historical records. As examples, we have found civil and military construction during that époque to be poorly represented, as is technology associated with marine navigation, development and exploitation of mines, etc. Some of these issues will be discussed later based on data located at the General Archives of the Indias in Seville, Spain.

There were developments in support of education and research in the Spanish Colonies. The University of Mexico, founded in 1553 by Luis de Velasco (father), included a faculty of medicine. There is a reference to a book on physics, Phisica Speculatio, written in Latin by Priest Alonso de la Veracruz (who was also the founder of the University of Michoacán). This book was printed in Mexico City at the atelier of Juan Pablos in 1557. The importation of the first printing press into Mexico occurred in 1536. This XVIth Century event was 104 years before the first printing press was imported into the British Colonies in the future United States of America. ${ }^{11}$ This is important when one considers development of cultural resources in the New World.

\section{INTRODUCTORY CHRONOLOGICAL DATA}

To seek to minimize confusion between Luis de Velasco (father and son), throughout the text we refer to the second Viceroy of these Spanish territories (1550 to 1564 AD) as "the father." Both father and son were very important individuals in the XVIth century. They organized a large number of explorations throughout the American continents and benefited from the favors and influence of the then King of Spain, Phillip II (Table 1). Importantly, both the father and the son sought meaningfully to improve the lives of Native American populations. This contrasts with the unfortunate treatment of Native Americans by numerous others. Here, we do not consider their lives in detail, rather we discuss issues relevant to this research. There is an excellent biography of the second Viceroy (father), with many comments of interest regarding the life of his son. ${ }^{14}$

When one examines the life of Luis de Velasco (son), one encounters marked controversy relative to the chronology (Tables 2 to 5). We present in as orderly a manner as possible a picture of events, but there are a number of uncertainties. This section of this 
TABLE 1.

Partial chronology of the Royal Family.

1527: Future King Phillip II born on May 21, 1527. On

September 28, 1559, Phillip II recognized as his half-brother, "Jeromin," born in 1547. This individual became known later as Don Juan of Austria, the hero of the Battle of Lepanto against Turkey. Jeromin was raised by Doña Magdelena de Ulloa in Villagarcia de Campos and was treated by her as if he was her own son. Doña Magdelena was a powerful and wealthy personage. She was related to the de Velasco family and also provided the money to build the Colegiata de San Luis. She died on June 11, 1598, in the same year as Phillip II. The framed painting in Fig. 3 hung for centuries in a Chapel built in memory of Doña Inez de Salazar y Mendoza at the Colegiata. Doña Inez died in 1636. The full name of "the father" was Luis de Velasco y Mendoza. In the $1960^{\prime}$ s, the painting ${ }^{12,13}$ (Fig. 3) was transferred to the

Sacristy of the Church at the Colegiata—now also serving as a museum.

1554: Prince Phillip married Mary Tudor of England on July 25, 1554.

1556-1598: Reign of Phillip II (he died in 1598 at the age of 71 years).

1598-1621: Reign of Phillip III (he died in 1621).

article leans heavily on data obtained during lengthy visits to the General Archives of the Indias in Seville.

Relative to the chronology developed in Table 2, Luis de Velasco (father and son) left Spain from the port of Sanlúcar de Barrameda (Huelva, Andalusia) on May 27, 1550, in the San Miguel "nao" (a boat of that époque). As a teenager, the son accompanied his father, who had been appointed the Viceroy of New Spain. Also, an uncle,

\section{TABLE 2.}

Chronology based on ca. 580 documents pertaining to de Velasco (son) at the Archivo General de Indias, Seville, Spain.

1532: Luis de Velasco (son). Later, he was named the Marquis of Salinas. Born in Carrión de los Condes (Palencia, Castilla, Spain).

1550 (he was 18 years old in 1550 if born in 1532): Leaves

Spain for Mexico with his father.

1550-1585 Lives in Mexico (continuously living in the New

World for 35 years, his home was in Mexico. He traveled to

California, New Mexico, and Florida in the future U.S.A.).

1585: Travel to Spain (he was 53 years old-now presbyopic).

1585-1589: Lived in Spain, returning December 1589.

1590-1595: Returned to Mexico, First Period as Viceroy of

España en Nuevo Mundo y/o Nuevo Mexico (Viceroy of

Spain in the New World, and/or New Mexico).

1595-1602: Peru (Lima), served as Viceroy of Peru.

1602-1607: Mexico.

1607-1611: Mexico, served a Second Term as Viceroy of

España in Nuevo Mundo y/o Nuevo Mexico.

1611: Leaves Mexico for Spain.

1611-1617: Serves in Spain as President of the Council of the Indias.

1617: Died in Seville, Spain (age 85).
TABLE 3.

Chronology from Larousse Encyclopedia. ${ }^{15}$

1539: Luis de Velasco (son), Marquis de Salinas. Born in Carrión de los Condes (Palencia, Castile, Spain).

1550-1564: Accompanied father to Mexico when he became second Viceroy of New Spain. If the son travelled to Mexico in 1550 and had been born in 1539, he would have been 11 years old.

1584: De Velasco (son) returned to Spain after the death of his father. He travelled a number of times in behalf of King Phillip II including service as Ambassador to Flanders

(including the Netherlands).

1590: Returns to Mexico.

1590-1595: First term as Viceroy of Nuevo Mundo and/or

Nuevo Mexico. Travels all over Mexico including Jalisco, Guanajuanto, Zacatecas, Saint Luis de Potosi.

1596-1604: Viceroy of Peru. Travelled all along the Pacific Coast.

1604: Returns to Mexico, at least, in part, resided in the City of Azcepotzalco.

1607-1611: Second term as Viceroy of Nuevo Mundo y/o

Nuevo Mexico.

1611: Returns to Spain.

1611-1617: Served as President of the Council of the Indias.

1616: Died in Seville, Spain (age 77).

Francisco de Velasco, and a cousin, Rodrigo de Vivero y Velasco, traveled on the same boat. Other members of the family remained in Spain. The son lived with his father in the Colonies, mainly in Mexico. After the death of his father, in 1564, he remained living in Mexico. There is controversy as to when de Velasco, the son, was born (estimates range between 1532 and 1539, see below) and whether he accompanied his father to Mexico in 1550 or arrived at a later date. De Velasco, the son, returned to Spain in 1585 , only to return again to Mexico in December 1589. During this trip to Spain he apparently served as Ambassador to either Flanders or (and?) Tuscany (Florence) for a period of time. He served on the city council, was appointed mayor of the city of Zempoala (or Cempoala), and may also have been mayor of Mexico City. In 1590, King Phillip II (Table 1) appointed him as the Eighth Viceroy of New Spain. His first term as Viceroy lasted until 1595. The painting of Luis de Velasco (son) seen in Fig. 1 depicts him during his first term as Viceroy. He is depicted wearing a spectacle correction. In 1595 or 1596, he was appointed as Viceroy of Peru. In 1602 , he asked to be relieved of this post. He indicated a preference to live in Mexico for the reminder of his days. On June 16, 1607, he received a Royal order (this time from King Phillip III) (Table 1), appointing him once again as (the Eleventh) Viceroy of New Spain. He served in this role until 1611. There is another portrait that was painted during his second term as Viceroy (in this portrait, he is shown wearing the same set of spectacles). At the end of his second term he experienced difficulties remaining in Mexico, and although Luis de Velasco (son) opposed an additional new appointment, King Phillip III asked him to serve as President of the Indias Council in Spain. He left Mexico on June 11, 1611, departing from the Port of Veracruz. He died in Spain in 1616 or 1617.

During the period between 1595 and 1607, important expansions of the Spanish colonies took place to the North in Mexico. 
TABLE 4.

Chronology by Dr. John Schwaller. ${ }^{16-18}$

Schwaller discusses a recently published book on de Velasco (son) by Juan Pablo Salazar Andreu (1997) ${ }^{16}$ as well as his own forthcoming book about de Velasco (son).

1539: Luis de Velasco (son) was born (this agrees with the Larousse chronology). Schwaller speaks strongly on this issue, ${ }^{16-18}$ i.e., he disagrees with Salazar Andreu ${ }^{16}$ (as well as Table 2, which was taken from sources located at the General Archives of the Indias, Seville). Salazar Andreu had indicated de Velasco (son) was born in 1534 and accompanied his father to the Americas when he (the father) was named the second Viceroy in 1550 AD. If born in 1534, de Velasco, the son, would have been 16 years old on arrival in the New World in 1550 and would have died at 83 years of age if he died in 1617. If born in 1539, as suggested by Schwaller, de Velasco (son) would have been 11 years old in 1550 and died at 78 years of age if he died in 1617 .

According to Schwaller, de Velasco (son) may not have accompanied his father to Mexico.) He states that in a letter written by de Velasco (son) to King Phillip II late during his stay in Peru (the letter is located in the General Archives of the Indias in Seville, Spain), de Velasco (son) stated that he accompanied the then Prince Phillip, later King Phillip II, to England for his marriage to Mary Tudor on July 25, 1554 (Table 1). On this occasion, he accompanied the wedding party including his older brother. ${ }^{19}$ If, as stated, the letter was written late during de Velasco (son's) period as Viceroy in Peru, perhaps this communication had been directed to King Phillip III. That is, Phillip II died in 1598, and Luis de Velasco (son) served as Viceroy in Peru from 1596 to 1602 see General Archives of the Indias in Seville chronology, or 1596-1604-see Larousse chronology, or Schwaller chronology.

1560: According to Schwaller, this was approximately the time when de Velasco (son) travelled to Mexico. While in Mexico, the son participated in uncovering the highly significant "Cortez Conspiracy". When he returned to Spain prior to serving his first term as Viceroy of The New World and New Mexico, de Velasco (son) also led an embassy to the court of the Grand Duke of Tuscany in Italy.

1590-1595: First term as Viceroy of the New World and New Mexico. He notes, in 1590, de Velasco prepared a series of ordinances addressing the distribution of mercury in the New World.

1596-1604: Serves as Viceroy of Peru.

1607-1611: Second term as Viceroy of the New World and

New Mexico, etc.

1617: Dies in Seville (age 78).

This area was named New Mexico, and there was also expansion along the Northern Coast of California.

There are useful Internet sites providing added data/information on the Viceroys of Mexico. ${ }^{20}$ Included are the drawings/paintings of the several Viceroys.

\section{USE OF SPECTACLES IN THE SPANISH COLONIES IN THE AMERICAS IN THE LATE XVIth CENTURY}

There is a portrait of Luis de Velasco (son) executed during his first term as "Viceroy of the New World, New Spain, and New

\section{TABLE 5.}

Chronology, Enciclopedia Universal Ilustrada: EuropeoAmericana, Vol LXVII, Espaso-Calpe, 1929. ${ }^{17}$

1534: Born in Carrión de los Condes, Castilla or in Mexico. 1557: Travelled to New Spain at the request of his father (not in 1550 AD). He lived in Cempoala in Mexico. Later he served for a period of time as Ambassador of Spain in Florence, Italy.

1590-1595: De Velasco (son) was appointed Viceroy of Mexico (first term). During this appointment period, De Velasco organized the expedition of Juan de Oñate for the conquest of New Mexico (in the future U.S.A.).

1595-not defined here: De Velasco (son) was appointed Viceroy of Peru.

1607-1611: He served his second term as Viceroy of Mexico and New Spain. His term was terminated when he was called by King Philip III to serve as President of the Council of the Indias in Spain. In recognition of his many contributions, he was named Marqués de Salinas.

1617: Died September 7.

Mexico." It has great historical value. It is situated in the Museum of the Pecos National Historical Monument, which is near Pecos, New Mexico; Pecos is not far from Santa Fe. This historical monument is at the terminus of the "Pecos trail" which led west across the modern-day United States of America. This photographic copy was first noted by author JME during a visit to the museum at that site some years ago. The copy of the portrait of de Velasco (son) has no information as to the artist nor date of its being painted and is of excellent quality (Fig. 1).

The Viceroy is shown wearing spectacles, there is a hint of some anomaly in the left eye, and prismatic effects are seen through the painted lenses. The lenses are mounted in a frame and have round contours. There is a "pince nez" form of bridge to help secure the frame to the nose. The relatively rounded shape of the arched bridge, the so-called "quevedos," oft-times made from whale baleen (a comment by Dr. J. William Rosenthal), appeared in the $\mathrm{XV}$ th century. There is a nonrigid temple structure (ear loops) made with fabric or organic material used to maintain the contact between the frame and the ears.

Prof. Kurt Bernardo Wolf (Kurt Bernardo Wolf. Personal communications dated February 5 and 9, 2003. Prof. Wolf is a physicist at the U. Nacional Autonoma de Mexico, Cuernevaca, Morelos, Mexico. Also, personal communication by Arq. Raphael Fierro Gossman of Mexico City, Feb. 18, 2003.) viewed the original viceregal portraits in the Chapultepec Museum in Mexico some years ago (it is possible that it may still be located there, a point that is being researched with the aid of Prof. Wolf and the brother of one of Wolf s sources, Arq., Rafael Fierro Gossman). Wolf stated, "I recall it (the portrait de Velasco [son] during his first term as Viceroy-authors' clarification) well, because it looked so quaint (children would say 'funny')." Wolf added that he noticed the distortion of his (de Velasco's [son] — authors' comment) eyes by the lenses, so they were probably not only for adornment. Today the portrait(s) are at the Museo Nacional del Virreinato (Plaza Higaldo No. 99, Edo. De Mexico-the author's map places the Pinacoteca Verrinal on Av. Dr. Mora [near Alameda Park and the Plaza Hidalgo, there is another painting probable at the Cabildo 
Metropolitano-Mexico City's Government building-in La Galeria de Los Retratos, and still another in the Museo Franz Mayer also on Av. Hidalgo opposite the Alameda Park]). Construction at some of these sites makes accessibility of some of these portraits questionable.

Reproductions of Fig. 1 (all in black and white) appear in a variety of locations, including the first Internet page cited, which is from the National Archives of Mexico. ${ }^{20}$ However, at this Internet site, there is confusion among the portraits. For example, Luis deVelasco's (father) portrait is shown both during his own term and also as serving (long alter his death) during the first term of de Velasco (son), and the portrait from the son's first term is presented during his second term as Viceroy.

In his second communication, Wolf wrote, "My recollection is

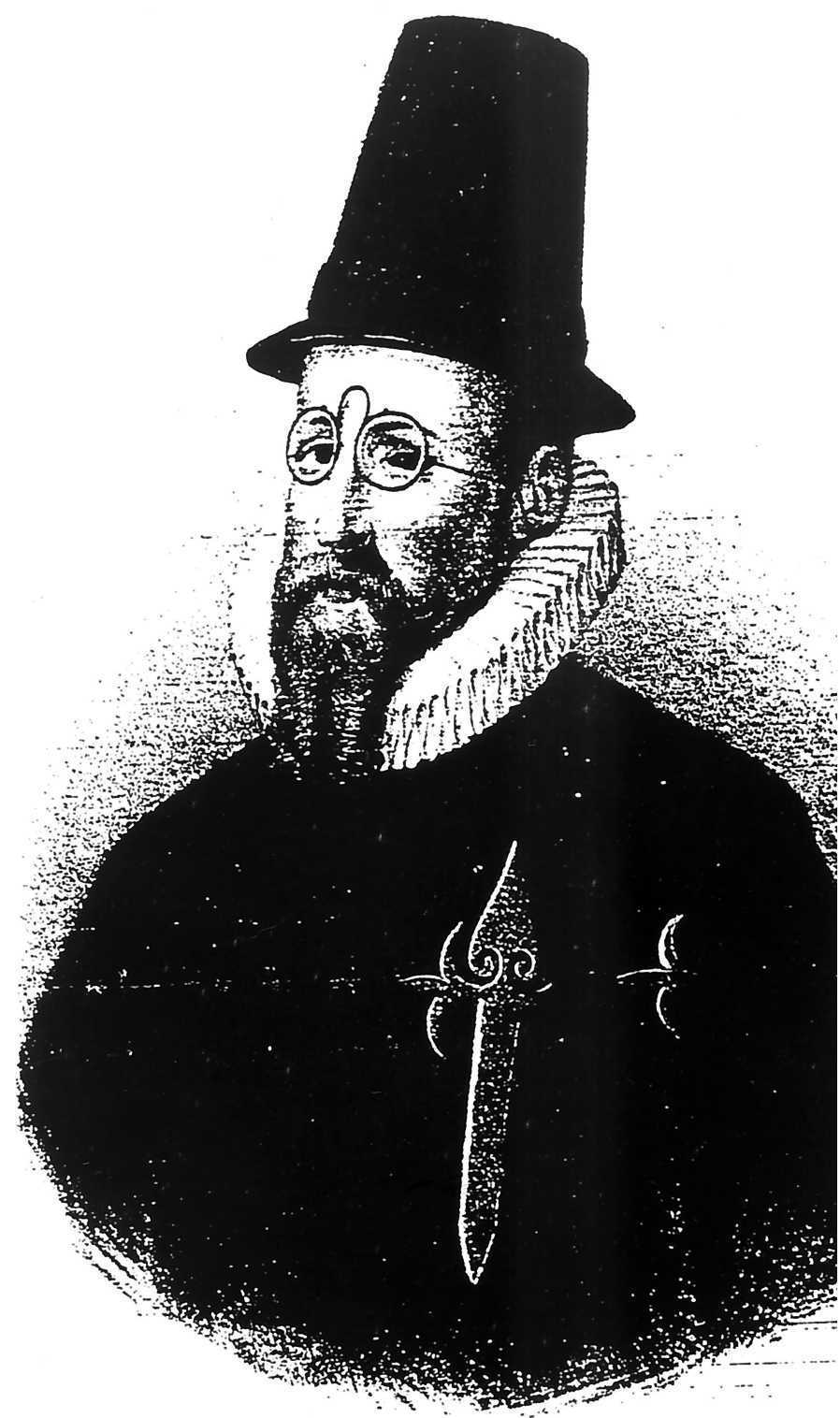

\section{FIGURE 1.}

Portrait of the Eighth (1590 to 1595 AD) Viceroy of New Spain, Luis de Velasco (son). This same gentleman was appointed to a second term as Eleventh Viceroy of New Spain (1607 to 1611 AD). The artist is unknown. This Figure is identical to the portrait displayed in the Pecos National Monument Museum. that of a long room, with paintings of the Viceroys, each canvas some $80 \times 120 \mathrm{~cm}$, two rows high and some 32 (paintings) long (there were 64 viceroys I think), oil paintings in color, that I saw last around 1955 or so. They seemed 'really' old paintings, although they may have been a recompilation of copies. I can't say what color his (de Velasco's [son]—authors' clarification) eyes were." (Kurt Bernardo Wolf. Personal communications dated February 5 and 9, 2003. Also, personal communication by Arq. Raphael Fierro Gossman of Mexico City, Feb. 18, 2003.) See the discussion below about the son's eye color.

The portraits of de Velasco (son) during each of his two terms as Viceroy are very similar. This suggests that he actually wore this correction. The only differences observed in the two black and white copies of these viceregal portraits are in the gray-white color of de Velasco's beard and hair in the later portrait, the position of his one hand (during his second term), and a very slight reduction in the bowing of the bridge on the second portrait. Otherwise they seem identical.

It is also true that Luis de Velasco (the son) was considered a learned person of his time (as was his father). Among the son's several initiatives, he founded the Royal Hospital in Mexico City, and he had interest in mining technology (e.g., he opened new mines in St. Louis Potosi); he organized exploratory expeditions (e.g., to "New Mexico" in the future United States, etc.).

We assume Luis de Velasco (son) did wear the correction shown in Fig. 1. He is the first of the viceroys shown wearing spectacles in this set of portraits.

\section{WHERE AND WHEN WERE THE SPECTACLES OBTAINED?}

We have struggled with the question of whether de Velasco (son) obtain his spectacle correction during his long period of residence in Mexico and other venues within the Spanish Colonies (including parts of the future U.S.) or whether these spectacles were obtained in Europe during his residence there from 1585 to December 1589. He returned to Mexico late in 1589 to begin his first term as Viceroy in 1590. To resolve the questions, the status of optical and ophthalmic development in the Spanish Colonies in the Americas is reviewed briefly below (this evidence is very fragmentary), but it was logical to assume that if such technology was available in Colonial centers, the Viceroy would have had access to it. de Velasco's travels and roles in Spain and Europe between 1585 and 1599 were examined for any hint of purchase/adaptation to the spectacle corrections. There is a rather unique and time-sensitive feature found in the de Velasco frame, that is, the presence of "ear loops."

In the booklet by Davidson and MacGregor, Spectacles, Lorgnettes, and Monacles, there is a table, "English Terminology for Spectacles," by MacGregor dated January 13, 1999. ${ }^{21}$ It provides an outline of visual corrections and spectacle development since $1285 \mathrm{AD}$. In this table, under the heading "Nose Spectacles Without Temples (Sides)" the following entry is found: "circa 1580, Spanish spectacles with ear loops" were introduced (words in italics are implied — note added by authors). There is no citation associated with this statement, although there are limited references provided for the book as a whole cited on p. $40 .{ }^{21}$ We also have available a copy of an engraving of an individual wearing spectacles 
with ear loops dated $1580 \mathrm{AD}$ (stated as being of Spanish origin) from an unattributed source-possibly English.

Corson $^{22}$ states that ear loops were developed in Spain and Italy in ca 1580 . He presents an engraving of a painting by J. Rottyer, ca 1580 or 1581, of Girolamo Capivaccio, a Professor of Philosophy and Medicine in Padua, Italy. Capivaccio is shown wearing bridged spectacles with ear loops. ${ }^{22}$ In this same citation, it is noted that Spanish Jesuits introduced ear loop spectacles to the Chinese, who utilized them broadly for the following 200 years.

In Mexico, there is a portrait of Don Manuel de la Bárcena, a member of the Provisional Committee of the Mexican government, whose members signed the Charter of Independence of the Mexican Empire in Mexico City, September 28, 1821. Here, too, although a different frame is seen, ear loops were being used in Mexico >200 years after the viceregal terms of de Velasco (son). Fig. 2, courtesy of Dr. Carmen Tato, shows a profile view of Bárcena.

El Greco's (1548 to 1614 AD) "Painting of a Cardinal" is found in New York City. In the gallery, the painting is stated to be ca $1600 \mathrm{AD}^{23,24}$ This painting is part of the donated Havemeyer Collection at the Metropolitan Museum of Art. The Cardinal is shown wearing ear loop spectacles. It is generally stated that this is a painting of the Inquisidor-General, Cardinal Don Fernando Niño de Guevara, who visited Toledo between 1599 and 1601 . The curators at the Museum state that it is not clear whether this is a portrait of de Guevara because there were two other resident Cardinal Archbishops in Toledo at the same time. They were Don Gaspar de Quiroga and Don Bernardo de Sandoval y Rojas.

Thus, the ear loop spectacles worn by Luis de Velasco (son) during his terms as Viceroy, 1590 to 1595 and 1607 to 1611, are

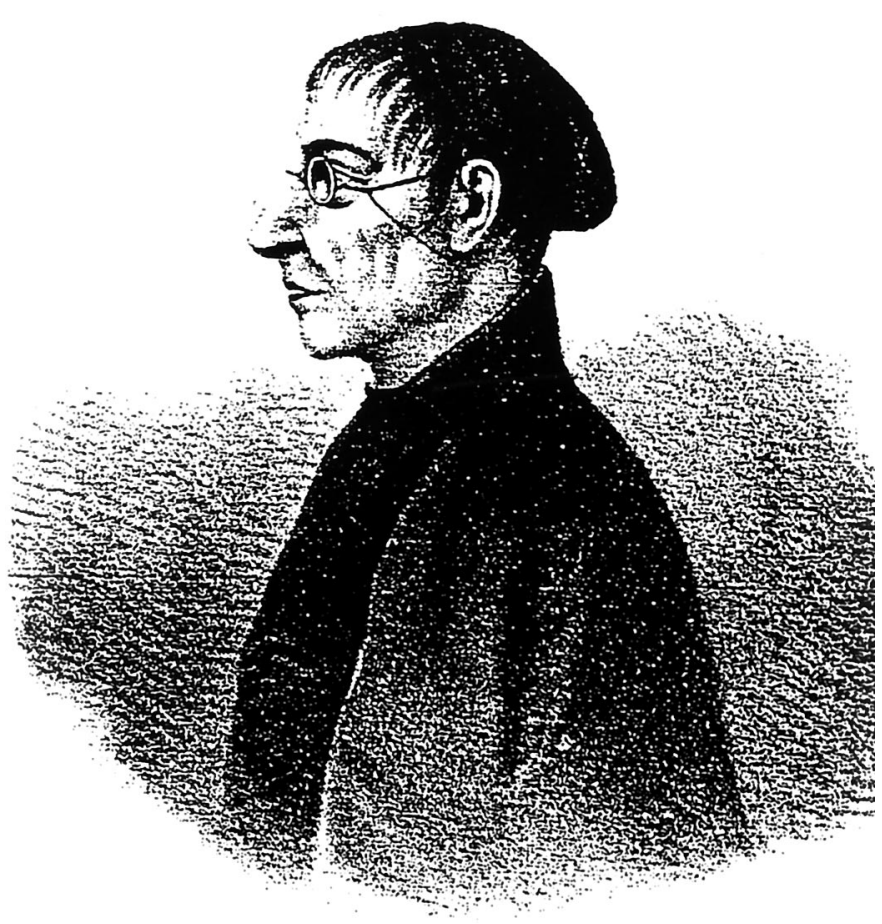

FIGURE 2.

Portrait of Manuel de la Bárcena. The portraits shown in Figs. 1 and 2 were obtained in a set of correspondence from Dr. Carmen Tato to Dr. C. Letocha. We cannot locate Dr. Tato at this time. consistent with the introduction of ear loop temples in about 1580 in Spain and Italy. His ear loops are a bit different than others portrayed, i.e., they have a single temporal strand with a near circular loop over each ear. Others have a loop originating at the temporal end of the spectacle frame; the material employed loops around the ear and returns to the same position on the spectacle frame (as in Fig. 2).

Accepting that de Velasco was in Spain between 1585 and 1589 and probably served as Ambassador to Flanders or Florence (see chronologies), it would be reasonable to suggest he could have readily obtained these spectacles in Europe. However, as indicated above, even reasonably new technology should have been available in the Colonies — at least to the Viceroy of New Spain. The latter assumes that some individual in at least one of the colonial centers was capable of properly selecting, fitting, and, by inference, maintaining de Velasco's spectacle correction. Maintenance of the lens/ frame combination had to be addressed, regardless of where he obtained the spectacles. It is possible that he had more than one pair, but they would still need to be fitted, adjusted, etc. Thus, the issue of where and when he obtained the spectacle correction remains as yet unresolved.

\section{DATA ON OPTICAL TECHNOLOGY IN THE SPANISH COLONIES}

It is important to clarify the state of the Colonies with respect to certain technological advances during the pertinent time period. This is based on details of possible instrumentation requiring optical technology. If one inspects the section "Maps, Charts, Engines and Samples" located in the General Archives of the Indias in Seville, one encounters $>10,000$ documents. All of the following items are mentioned in the Archive titled "Audiencia de Mexico." They are presented in approximately chronological order:

1. Astronomical observations of the moon, dated in Puerto Rico between 1561 and 1600 .

2. Design of a grid system and a spyglass dated 1633 without reference to a specific location.

3. A drawing describing the construction (or plans) of the telescope located on the jutting rock of "El Morro" in the port of La Havana, Cuba. This drawing is from a document dated 1809. It is probable that the idea and design for this telescope occurred earlier than this date.

4. A meaningful number of military patents.

5. So called "objects for sale," among which, for example, there was a form of magnifier used to inspect the quality of fabrics and other elements.

6. Techniques for scuba diving A curious design named "hydroandric machine designed for wear under water." This device, designed by Alejandro Durand in 1720 in Lima, Peru, was comprised of goggles (made of glass) and was used to protect the eyes of the individual wearing them in an aquatic environment.

Dr. J. William Rosenthal (personal communication) pointed out to JME that the first trade establishment created at the Jamestown Colony in Virginia (1608), was a "glass house" which failed as a business. This indicates the importance of such a service and suggests the availability of a pair of skilled hands within the group of settlers. In his book, Rosenthal ${ }^{25}$ also calls attention to glass 
being made in 1535 in Puebla de Los Angeles, Mexico, and also in Cordova del Tucamen, Rio de La Plata Territory, Argentina, in 1592. However, no details nor citations are provided that discuss whether spectacles were made at these locations.

Once again, we argue that associated with the expansion of the Colonies, an important influx of European technology took place. This most probably resulted in the creation of infrastructural resources particularly at critical locations, e.g., in Mexico City (built on the ancient Aztec City of Tenochtitlán), in the city of La Havana, in San Juan de Puerto Rico, in Lima, and in other places of special relevance. So saying, available evidence is limited suggesting establishment of ophthalmic services. However, the growing numbers of individuals present in these colonies and the aging of those present in the colonies argues for development of some such services.

\section{THE THIRD PORTRAIT}

A third portrait of Luis de Velasco (the son) exists. It also includes the father. ${ }^{12,13}$ This is a painting located in the Museum of the Colegiata de San Luis in the village of Villagarcia de Campos (Valladolid, Castilla). According to the historian Demetrio Ramos, ${ }^{12,} 13$ in the complete painting (key portions of the painting are seen in Fig. 3), Luis de Velasco (son) is painted as a young man standing close to his father, and there appear three added individ-

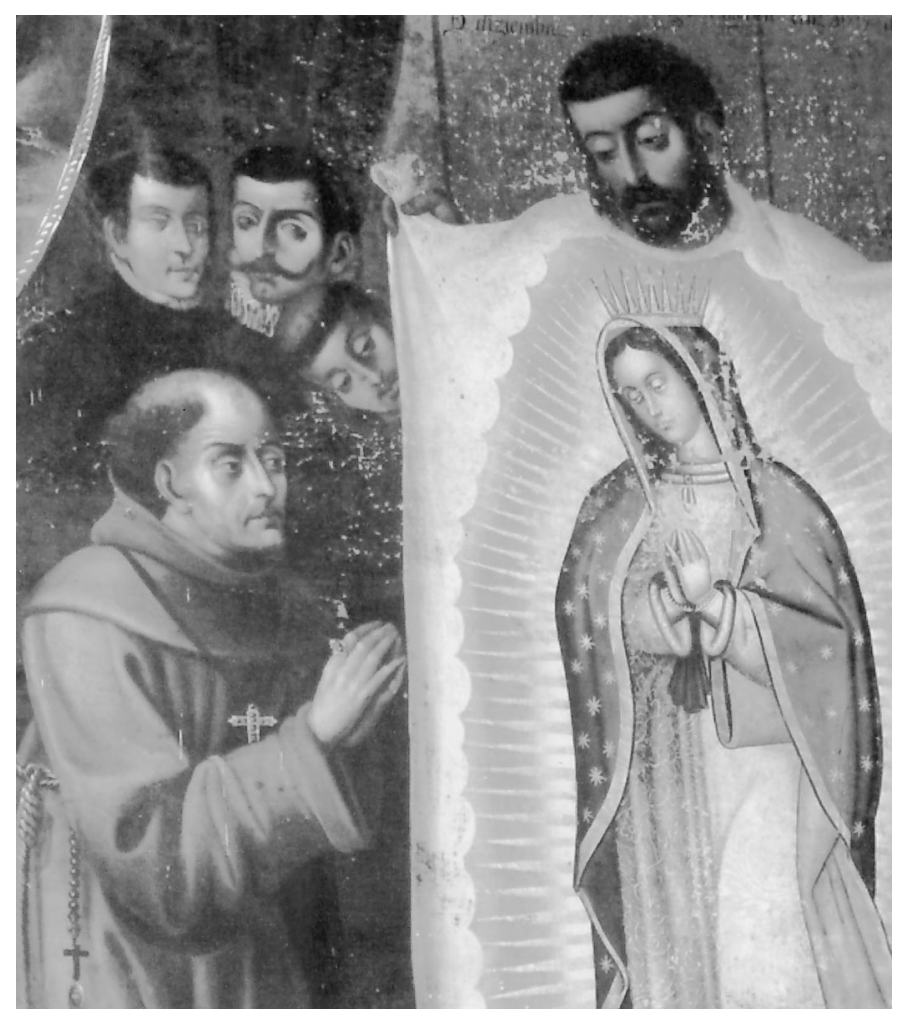

\section{FIGURE 3.}

A major portion of a painting by Juan Dualde (not dated). It is located in the Sacristy of the Colegiata de San Luis (small cathedral) of the village of Villagarcía de Campos (near Valladolid, Castilla, Spain). The Second Viceroy, Luis de Velasco (the father), is the gentleman to the upper left of the picture with the beard. The young man next to him is Luis de Velasco (the son). Here, the son is much younger than seen in Fig. 1, and he is not wearing a visual correction. uals (two Franciscan monks, one served as the first Bishop of Mexico, Juan de Zumárraga de Vasco de Quiroga [the gentleman praying], and the recently canonized Native-American Saint Juan Diego [with a beard] is observed holding open the cloth of his cloak revealing the Virgin of Guadaloupe]). Luis de Velasco (the son)'s portrait is that of a young man who is depicted not wearing a visual correction. His eyes were depicted as blue and appeared distinctly different from all others in the painting (discussed in greater detail below). They also look a bit "puffy," or he may have had a bit of a squint (also see Fig. 1).

\section{DISCUSSION OF TABLES}

There are important discrepancies in the assembled chronologies as they relate to this analysis, particularly as regards de Velasco's date and place of birth. At the time he first became Viceroy in 1590, Table 2 suggests he would have been 58 years old; Salazar Andreu ${ }^{16}$ (Table 4) and the Enciclopedia Universal Ilustrada document ${ }^{17}$ (Table 5) indicate he would have been 56 years old; and Larousse $^{15}$ and Schwaller ${ }^{18}$ suggest he would have been 51 years old. At each of these ages, he would have exhibited presbyopia at the time his first (known) portrait (wearing a spectacle correction) was painted, that is, after the son started his first term as Viceroy. Table 5 suggests that the son was born in either Spain or Mexico. At the town of Carrión de los Condes (Palencia, Castilla, Spain), where most chronologies state that Luis de Velasco (son) was born, town records were destroyed during battle with the French, and, thus, valuable records were lost.

Separately, before his first term as Viceroy, the Larousse chronology (Table 3) indicates that he served for some period of time between 1585 and 1590 as Ambassador to Flanders (during a return to Spain). And John Schwaller (Table 4) notes that de Velasco (son) served for a period of time as Ambassador to the Duke of Tuscany (Italy). The Enciclopedia Universal Ilustrada (Table 5) states that de Velasco was Ambassador to Florence on behalf of Spain before his serving his first term as Viceroy.

Both locations, Flanders and Tuscany/Florence (e.g., see Ilardi ${ }^{7}$ ), had existing optical resources of note at that time. Given other considerations, these two locations were then most probably more advanced in optics than New Spain and possibly more advanced than Spain. There are suggestions that de Velasco (son) served in other posts in Mexico during the 5-year period before his becoming Viceroy for the first time.

The picture shown in Fig. 3 is important in a number of regards. It is not clear whether this painting was created after de Velasco's death in 1616 (Table 3) or in 1617 (Tables 2, 4, and 5), or at an earlier time. The postmortem or briefly antemortem time of painting this portrait was suggested by a number of sources. It was donated to the Colegiata de San Luis near Valladolid in the midXVIIth Century by a member(s) of the de Velasco family. The artist was Juan Dualde, and the painting is signed but not dated. This large painting is bolted to the wall above a door. There is some information written on the reverse side, but this was not accessible to us, nor were the written comments known to the Fathers present, nor is this information stated in the inventory of the Colegiata de San Luis.

In Fig. 3, the age of the son appears to be in his early 20s. As stated above, he is shown with blue eyes (all other individuals 
portrayed have dark iridis). He has a paler complexion, rather puffy eyelids, and possibly some suggestion of convergent eye turn. Is it possible that he was an accommodative esotrope? He had dark hair, but not quite as brown or dark as his father's.

There is a near-vertical lineal fleck of paint missing that extends from above the son's upper lid margin across his left iris (the missing fleck is perhaps $1.0 \mathrm{~mm}$ wide and appears white). Flecks of paint are missing at a number of locations on the painting. Fleck frequency supports the notion that the painting had been rolled up one or more times over a period of time and/or was subject to rough handling. There are also differences in fleck orientations. When observing the full-color original, many of the white flecks are not as obvious as when gazing at this black/white/gray scale rendition of the painting (Fig. 3).

In comparison, Fig. 1 shows de Velasco (son) in his middle years wearing glasses and having dark iridis. However, copies of the official portraits of the viceroys are shown in black and white, and we cannot judge iris color from such renditions. Thus, we will not comment further on this point. Further research on this matter needs to be conducted on the original portraits of the viceroys in Mexico. The second Viceregal portrait adds virtually no information except that he had aged. In candor, the second portrait appears as a slightly modified copy of the first portrait. In Fig. 1, there seems to be some irregularity present associated with his left eye.

As indicated, we do not know when Fig. 3 was painted by Juan Dualde. Although there are statements indicating that it was painted late in the life of de Velasco (son), ${ }^{12,13}$ one can just as well argue that it was painted earlier in Mexico and carried rolled up to Spain. It was later framed and then finally placed in the Chapel of Doña Inez de Salazar y Mendoza. As noted, the painting includes de Velasco, father and son, the first Bishop of Mexico, who was a distinguished Franciscan Father, and another Franciscan. Also seen is the recently declared saint, the first Native American so declared, Juan Diego (head leaning over the top of the sheet-like cloak with the image of the Virgin of Guadaloupe). The general theme of the painting is related to the very sincere and enduring Mexican devotion to the Virgin of Guadaloupe, and the association of that devotion to the (now) Saint Juan Diego. The Velascos belonged to an old noble family of Castilla with strong ties to the Colegiata. Therefore, it is not strange that they would wish to be represented in a painting that was going to be given to the Colegiata de San Luis in Villagarcia de Campos near to Valladollid, and given the history of father and son, it is reasonable that this painting exhibits strong Mexican influences.

The specific features recorded in this picture raise questions relating to when de Velasco (son) received a probable visual correction for either hyperopia and/or presbyopia or both. It would be desirable to know when this painting really was executed. That is, did the artist paint the subjects from life, or from descriptions provided by family member(s) or friends? Does this picture portray father and son while the father was Viceroy? It is unfortunate that the age of de Velasco (son) seems so uncertain. Considerable caution in interpretation must be exercised.

As noted, the painting depicted in Fig. 3 hangs in the Colegiata de San Luis. The local guidebook has considerable information on a number of the involved personages. We have explored this site. This Colegiata was an important training site for Jesuit missionaries, a large number of whom were trained to serve the native pop- ulations in New Spain. Such a role was also featured in the administrative actions of both of the de Velasco Viceroys. The Jesuits played a meaningful role in educating, making health care available, and providing appropriate employment for the Native American population(s). As a familiar example, the young missionaries pictured some years ago in the movie "the Mission" were trained in this Colegiata (the story portrayed in that movie was largely based on fact).

The Colegiata was funded by the de Ulloa family and built in 1580; it had 350 scholars in residence by 1585 . Doña Magdelena de Ulloa (died 1598) was related to the de Velasco family. A book on her life has recently been written. ${ }^{12}$ In another reference, Arte Americanista, it was stated that Demetrio Ramos recorded the donation of the painting (Fig. 3) to the Colegiata. ${ }^{13}$ The painting apparently hung without a frame for some years until the wife of Antonio de la Cerda (23rd Viceroy of Nuevo Espagña, 1680 to 1686) paid to have it framed in 1689.

No additional evidence on these matters has been found by us. We await the book cited in preparation by Schwaller ${ }^{18}$ and receipt of a copy of the Salazar Andreu book. ${ }^{16}$

\section{CONCLUSIONS}

We conclude that lens technology necessary for correcting vision and provision of spectacles could have been available in the New World Spanish Colonies during the time of service of Luis de Velasco (the son), and, if so, it is likely that the Viceroy would have had access to that technology. Luis de Velasco (son) had lived and served in Mexico for a lengthy period of time when his first portrait as Viceroy was painted (Fig. 1). However, before assuming the position of Viceroy, he returned to Spain between 1585 and December 1589. While there, he served in ambassadorial roles for the King Philip II of Spain either in Flanders or (and) Tuscany (Florence). The spectacles shown in Fig. 1 could also have been obtained readily either in Spain, Italy, or Flanders. While the latter seems the more likely scenario, no definitive statement can be made.

Please distinguish between first spectacle use and first known use of visual corrective devices in the Americas, New Spain and in the future United States. Only the latter of these two is considered here. As just stated, we do not know where de Velasco (son) obtained his visual correction. We assume that he actually wore them because they appeared in both of his formal portraits during his separated terms as Viceroy and evidence for lens-induced aberrations and some ocular anomaly exists in, at least, the first of these portraits and possibly the third (Kurt Bernardo Wolf. Personal communications dated February 5 and 9, 2003. Also, personal communication by Arq. Raphael Fierro Gossman of Mexico City, Feb. 18, 2003.). During the time periods he served as Viceroy, there is meaningful evidence that "the son" traveled in parts of the future United States (California, New Mexico, and Florida), and he organized an exploration specifically in the future New Mexico during his first term as Viceroy (see an important entry in Table 5).

De Velasco's (son) first term occurred before the settlement of the early French, Dutch, Swedish, and British Colonies along the East Coast of the North American Continent, i.e., before the initiation of the Virginia colonies (Jamestown, etc.) (1607), and the Plymouth Colony in Massachusetts (1620), but contemporary 
with or just after the attempted settlement of the so-called lost colony in North Carolina (site of the birth of Virginia Dare, who was baptized in 1585). Because we can place the son in parts of the future continental United States, his were the (for now) firstknown spectacle corrections used in this nation, and possibly the Americas in general. We have no information on this set of issues in Portuguese colonies at this time. And we cannot state whether any sea captains or crews of vessels conducting explorations wore visual corrections (it would not be surprising).

\section{ACKNOWLEDGMENTS}

This work has been supported in part by the "Fundacion Antonio del Amo" between the Complutense University of Madrid and the University of California. The authors thank responsible individuals in the Archivo General de Indias in Seville for making available the necessary facilities. Julian Bescós of the Ramón Areces Institution in Spain facilitated much of our work. We thank Dr. Charles Letocha, York, PA, for his kind assistance and for providing communications sent to him by Dr. Carmen Tato and Prof. Vincent Ilardi for sharing his copy of Devesa. We also thank Fathers Eliseo Abejon and Felix Rodriguez of the Colegiata de San Luis at Villagarcia de Campos in Castilla. Frank Barraclough of the Ophthalmic Antiquities International Collectors Club, UK, kindly obtained valuable references and materials for us, and we appreciate important comments by Prof. Kurt Bernardo Wolf of the Universidad Nacional Autonoma de Mexico, Cuernavaca, Mexico, and his friend/ associate Arq. Rafael Fierro Gossman of Mexico City and the valued information provided by Dr. J. William Rosenthal of New Orleans, LA.

Received December 27, 2002; revision received May 20, 2003.

\section{REFERENCES}

1. Enoch JM. Introducción a la historia de las lentes y correccciones visuales: una referencia a España y a los terriorios del nuevo mundo. In: Calvo Padilla, ML, ed. Óptica Avanzada. Barcelona: Ariel Ciencia, 2002:1-39.

2. Enoch JM. Archaeological optics. In: Guenther A, ed. International Trends in Applied Optics. Bellingham, WA: SPIE Press, 2002: 629-66.

3. Enoch JM. The enigma of early lens use: what is a lens? How do we know that an apparent lens was used as a lens? Tech Cult 1998;39: 273-91.

4. Enoch JM. First known lenses originating in Egypt about 4600 years ago. Doc Ophthalmol 1999;99:303-14.

5. Enoch JM. Concave mirrors used for visual corrections during the Renaissance and earlier. Atti della Fond. Georgio Ronchi 2001;56: 133-48.

6. Devesa B. Historia Gráfica de la Ótica. (A Graphic History of Optics). Celebration Edition. Colegio Oficial de Opticos y Optometristas (Spanish Society of Opticians and Optometrists). Barcelona: Jims SA, 1990.

7. Ilardi V. The role of Florence in the development and commerce in spectacles. Atti della Fond. Georgio Ronchi 2001;56:163-76.

8. Forbes RJ. Glass throughout the ages. Philips Tech Rev 1960/61;22: 2:81-344.

9. Gibbs R. Tommaso di Modena. New York: Cambridge University Press, 1989.
10. Enoch JM, Calvo ML. Evidence for the use of corrective lenses in Spain in the XVth century. Rev Esp de Fis 1998;12:55-7.

11. Fernández Vallin A. The scientific culture in Spain in the VXIth century. Coedición de América Quinto Centenario del Descubrimiento. Sevilla, Spain: Padilla Libros, 1989:292-3.

12. Ramós Peréz D. Portrait of a President of Council as a child, with his father (also) Viceroy Luis de Velasco, in a Gadaloupean painting. Valladolid, Spain: El Consejo de Indias en el siglo XVI, 1970:211-5.

13. Andrés Ordax S. 4.6 Juan de Zumárraga y el virrey Velasco ante la Virgin de Guadaloupe. pp.136-7. Virreyes, autoridades, oficiales y commerciantes. Junta de Castilla y León (Comisario Andrés Ordax, Salvador), Arte Americanista (Catalogue of exhibit in Valladolid, Castilla, Iglesia de la Magdelena, Del 11 de Noviembre al 11 Diciembre, 1992:234.

14. Sarabia Viejo, Ma. Justina. Luis de Velasco (father) Viceroy of New Spain (1550-1564). Sevilla, Spain: Publicaciones de la Escuela de Estudios Hispano-Americanos de Sevilla, CCXLIV, 1978.

15. Gran Enciclopedia Larousse, Vol 10. Barcelona: editorial Planeta, 1977:666.

16. Salazar Andreu JP. The government of New Spain of the Viceroy Luis de Velasco, the Son (1590-1595) and (1607-1611). Valladolid, Spain: Quirón Ediciones, 1997:301, Notes, Bibliography, Appendix.

17. Enciclopedia Universal Ilustrada: Europeo-Americana. Vol. LXVII. Barcelona, Espaso-Calpe, 1929:610-1.

18. Schwaller JF. Book Reviews (comparative). The Americas (TAM) 2000;57:295-7.

19. Latasa Vassallo P. Administración virreinal en Perú: Gobierno del Marqués de Montesclaros (1607-1615). Madrid: Editorial del Centro de Estudios Ramón Areces, 1997:xxxvi, 709, Footnotes, Maps, Bibliography.

20. National Archives of Mexico. Virreyes de la Nueva España (1519-1821). Available at: http://www.arts-history.mx/virreyes/ index.html and http://www.agn.gob.mx/publi/publi_agn02.html. Accessed October 2002.

21. Davidson DC, MacGregor RJS. Spectacles, Lorgnettes, and Monocles, 2nd ed. Princes Risborough, UK: Shire, 2002:38-9, see table "English Terminology for Spectacles" by RJS MacGregor dated January 13, 1999.

22. Corson R. Fashions in Eyeglasses, 2nd impression with supplement. London: Owen, 1980:33, Fig. 10.

23. O'Neill JP, ed. Metropolitan Museum of Art: Europe in the Age of the Monarchy. New York: The Metropolitan Museum of Art, 1987: 56-7, Fig. 39.

24. Use of the Spectacles for All Sorts of Views, annotated edition edited by INDO for the 350th anniversary of the edition of the book of Benito Daza de Valdés. Barcelona: INDO, 1972:35.

25. Rosenthal JW. Spectacles and Other Vision Aids: a History and Guide to Collecting. San Francisco: Norman Publishing, 1996:21.

Jay M. Enoch

School of Optometry

University of California at Berkeley

Berkeley, CA 94720-2020

e-mail: jmenoch@socrates.berkeley.edu 